\title{
Peningkatan pembelajaran table tennis melalui teknik holding bet pada siswa sekolah dasar
}

\section{Improving table tennis learning through the holding bet technique for elementary school students}

\author{
Nur Ahmad Muharram ${ }^{1}$, Setyo Harmono ${ }^{2}$ \\ 1,2 Universitas Nusantara PGRI Kediri \\ Email: nur.ahmad1988@unpkediri.ac.id ${ }^{1}$, setyoharmono@gmail.com ${ }^{2}$
}

\section{INFO ARTIKEL}

Diterima : 25 April 2021

Disetujui : 27 Mei 2021

Tersedia secara Online Mei 2021

\author{
Alamat Korespondensi: \\ Nur Ahmad Muharram \\ Universitas Nusantara PGRI Kediri \\ Jalan Kyai Haji Ahmad Dahlan 64112 \\ Mojoroto Jawa Timur \\ E-mail: \\ nur.ahmad1988@unpkediri.ac.id
}

\begin{abstract}
ABSTRAK
Tujuan penelitian adalah untuk mengetahui teknik memegang bet yang baik dapat meningkatkan pembelajaran tenis meja pada siswa kelas V Sekolah Dasar Negeri 5 Kediri. Metode penelitian menggunakan Penelitan Tindakan Kelas. Hasil penelitian saat pra siklus, 2 siswa (10\%) memperoleh ketuntasan dan 18 siswa (83\%) belum tuntas. Siklus I rata-rata meningkat 44 dimana 11 siswa (39\%) memperoleh ketuntasan dan 13 siswa (61\%) belum tuntas. Nilai observasi aktivitas siswa 69\% kategori penilaian baik secara klasikal. Siklus II meningkat 83,1 dimana 17 siswa (75\%) memperoleh ketuntasan, 3 siswa (25\%) belum tuntas dan nilai observasi aktivitas siswa meningkat $94,56 \%$ kategori penilaian baik sekali. Siklus III meningkat 92 dimana semua siswa sebanyak 25 (100\%) memperoleh ketuntasan dan nilai observasi aktivitas siswa meningkat $97 \%$ kategori penilaian sangat baik sekali. Disimpulkan bahwa modifikasi bet menggunakan holding bet dapat meningkatkan keefektifan belajar siswa dalam permainan tenis meja pada siswa kelas V Sekolah Dasar Negeri 5 Kediri.
\end{abstract}

Kata kunci: table tennis, holding bet, PTK.

The aim of the research was to find out that good bet-holding techniques can improve learning table tennis in fifth grade students of SD Negeri 5 Kediri. The research method uses Classroom Action Research. The results of the research during the pre-cycle, 2 students (10\%) obtained completeness and 18 students (83\%) had not yet completed. In the first cycle, the average increase was 44 where 11 students (39\%) had completed and 13 students (61\%) had not finished. The value of student activity observation is 69\%, the assessment category is classically good. Cycle II increased by 83.1 where 17 students (75\%) obtained completeness, 3 students (25\%) had not yet completed it and the value of student activity observation increased $94.56 \%$ in the category of excellent assessment. Cycle III increased 92 where all students as much as 25 (100\%) obtained completeness and the value of student activity observations increased $97 \%$, the assessment category was very good. It was concluded that the modification of the bet using the holding bet could increase the effectiveness of student learning in the game of table tennis for the fifth grade students of SD Negeri 5 Kediri.

Key words: table tennis, holding bet, PTK. 


\section{PENDAHULUAN}

Pembelajaran penjaskes merupakan suatu mata pelajaran akademik ataupun aspek dalam proses pembelajaran yang berkenaan dengan pertumbuhan serta keahlian gerak orang yang sukarela serta bermanfaat, dan berhubungan langsung dengan reaksi mental serta sosial (Mashud, 2018). Pada hakikatnya pembelajaran jasmani merupakan proses pembelajaran yang menggunakan kegiatan raga buat menciptakan pergantian holistik dalam mutu orang baik dalam perihal raga, mental dan emosional. Sekian banyak wujud kegiatan bermain, tenis meja ialah salah satu wujud game cabang berolahraga yang mempunyai nilai pembelajaran yang sangat besar. Oleh sebab itu game berolahraga tenis meja sepatutnya sudah diperkenalkan kepada kanak- kanak semenjak umur dini (Mashud, Hamid, \& Abdillah, 2019). Perihal ini pasti di perlukan sesuatu aksi yang menunjang terciptanya pendidikan yang efisien. Guru wajib terampil dalam memilah strategi pendidikan supaya pendidikan efisien, efektif, refleksi serta terus menerus buat senantiasa mencari revisi. Guru yang mengajar wajib senantiasa mencermati kesusahan siswa serta menguasai dan berupaya membiasakan bahan dengan partisipan didik. Sekolah Dasar (SD) ialah tempat yang sangat pas buat pembinaan dini demi pengembangan berolahraga tennis meja. Kanak-kanak sanggup memperlihatkan hal-hal yang sangat polos buat ditunjukan di samping itu pada umur ini umumnya kanakkanak banyak memakai waktunya buat bermain. Terlepas dari perihal itu seluruh, kedudukan seseorang guru sangat memastikan keberhasilan pembinaan cabang oleh raga ini. Game tenis meja ialah salah satu modul yang ada dalam kurikulum yang harus diajarkan serta diberikan di sekolah dasar. Pada game tenis meja ada sebagian metode dasar yang wajib absolut dipahami oleh seseorang pemain/atlet tenis meja ialah metode memegang bet yang benar. Metode ataupun metode memegang bisa pengaruhi hasil seseorang dalam melaksanakan pukulan bola. Bila bet dipegang dengan metode yang benar hingga hendak menciptakan pukulan yang memuaskan sehingga game tenis meja bisa sukses pula.

Dalam penerapan pendidikan tenis meja siswa kelas V di SD Negara 5 Kediri banyak menemui hambatan antara lain tidak tercapainya kriteria ketuntasan minimun (KKM) ialah nilai 67, terbatasnya waktu, terbatas fasilitas serta prasarana (BET) dan keahlian siswa sangat kurang dalam memahami metode memegang bet yang baik. Merujuk pada penjelasan di atas, permasalahan dalam riset ini bisa diformulasikan selaku berikut: apakah dengan metode memegang bet yang baik bisa tingkatkan pendidikan tenis meja pada siswa kelas V Sekolah Dasar Negara 5 Kediri. Tujuan riset ini adalah buat mengenali apakah dengan metode memegang bet yang baik bisa tingkatkan pendidikan tenis meja pada siswa kelas IV Sekolah Dasar Negara 5 Kediri. Inti dari pembelajaran itu merupakan seluruh upaya yang dilakukan oleh guru (pendidik) supaya terjadi proses belajar pada diri siswa. Secara implicit, di dalam pendidikan, terdapat aktivitas memilah, menetapkan serta meningkatkan tata cara buat mencaapai hasil pendidikan yang di idamkan. Pendidikan lebih menekankan pada cara-cara buat menggapai tujuan serta berkaitan dengan gimana metode mengorganisasikan modul pelajaran, mengantarkan modul pelajaran, serta mengelola pendidikan (Sutikno, 2013: 3132).

Tenis meja merupakan sesuatu cabang berolahraga yang tidak memahami batasan usia. Kanak- kanak ataupun orang berusia bisa bermain bersama (Simpson, 2004: 7). Tenis meja merupakan berolahraga raket yang populer di dunia serta jumlah partisipasinya menempati 
urutan kedua. Di Amerika serikat sendiri ada lebih dari 20 juta partisipan aktif, serta pada tahun 1988 dimasukan tenis meja dimasukan dalam olimpiade (Hodges, 2007: 1). Metode memegang bet ialah aspek yang sangat berarti dalam game tenis meja. Secara garis besar pegangan bisa dibedakan jadi 2 (2) berbagai ialah: b) Pegangan semacam berjabatan tangan (shakehand grip), b) Pegangan semacam memegang tangkai pena (penhold grip). Memantulkan bola ke atas dengan memakai bet. Mula-mula dicoba secara terpisah, misalnya dengan sisi forehand saja, ataupun backhand saja, setelah itu bisa dicoba dengan campuran forehand serta backhand. Latihan ini bisa dicoba pula sembari berjalan maju-mundur, ke samping kiri ataupun ke samping kanan (Nurlan Kusmaedi, dkk, 2005: 7) Belajar ialah serta aksi serta sikap siswa yang lingkungan. Selaku aksi, hingga belajar cuma dirasakan oleh siswa sendiri. Proses belajar terjalin berkat siswa mendapatkan suatu yang terdapat di area dekat. Area yang dipelajari oleh siswa berbentuk kondisi alam, benda-benda, hewan, tumbuhtumbuhan, manausia, ataupun hal-hal yang dijadikan bahan belajar. Aksi belajar tentang sesuatu perihal tersebut nampak selaku sikap belajar yang nampak dari luar (Dimyati, Mudjiono, 2013: 7).

\section{METODE}

Tata cara merupakan sesuatu metode yang digunakan buat membongkar permasalahan riset. Secara universal tata cara riset dimaksud selaku metode ilmiah buat memperoleh informasi dengan tujuan serta khasiat tertentu (Sugiyono, 2011: 3). Tata cara yang digunakan dalam riset ini merupakan tata cara deskriptif. Bagi Sumadi (2003: 76) Penelitian deskriptif merupakan riset yang bermaksud buat membuat deskripsi menimpa situasi-situasi ataupun kejadian-kejadian. Wujud riset merupakan riset aksi kelas, bagi Wardhani (2007: 1. 4) Riset Aksi Kelas merupakan riset yang dicoba oleh guru di dalam kelasnya sendiri lewat refleksi diri, dengan tujuan buat membetulkan kinerjanya selaku guru, sehingga hasil belajar siswa jadi bertambah. Riset aksi ialah sesuatu aktivitas siklustis yang bertabiat merata, yang terdiri dari analisis, temuan, kenyataan, konseptualisasi, perencanaan, penerapan serta temuan kenyataan bonus dan penilaian. Perihal ini di informasikan oleh Sanford," Analysis, fast finding, conceptualization, planning, execution, more fact finding or evaluation; and then a repetition of this whole circle of activities; indeed, a spiral of such circles". (Agung, 2012: 65) Prakteknya, PTK merupakan aksi yang bermakna lewat prosedur riset yang mencakup 4 langkah ialah: a) Merumuskan permasalahan serta merancang aksi (planning). b) Melakukan aksi (acting) serta pengamatan (observing). c) Merefleksikan (reflecting) hasil pengamatan. d) Revisi ataupun pergantian perencanaan (replanning) buat pengembangan tingkatan keberhasilan (Susilo, 2007: 16). Kristiyanto (2010: 28) menarangkan Peneltian Aksi Kelas (PTK) ialah bagian dari riset permasalahan instan yang mempunyai tujuan utama buat membetulkan mutu proses serta hasi pendidikan pembelajaran jasmani ataupun membetulkan mutu proses serta hasil kepelatihan berolahraga. Revisi tersebut dicoba dengan memakai prinsip kooperatif, kolaboratif, serta siklus action dalam membongkar permasalahan instan Posisi riset di Sekolah Dasar Negara 5 Kediri. Dipilihnya posisi ini sebab di Sekolah Dasar Negara 5 lagi tingkatkan hasil belajar siswa dalam pendidikan pukulan melambungkan bola ke atas memakai modifikasi bet. Subyek riset merupakan Siswa kelas IV Sekolah Dasar Negara 5 Kediri. 


\section{HASIL PENELITIAN}

Hasil dari uji serta observasi yang di bagikan, digunakan selaku dasar pengambilan kesimpulan. Apakah aktivitas yang sudah sukses. Bila pada siklus II ini masih banyak siswa yang hadapi kesusahan belajar serta kesalahan menuntaskan tugas, hingga hendak direncanakan siklus berikutnya ialah siklus III. Tetapi bila penanda keberhasilan belajar, sudah tercapai hingga tidak butuh dilanjutkan kesiklus selanjutnya. Desain riset secara garis besar terhadap 4 sesi yang dilalui dalam melakukan riset aksi kelas, ialah (1) Perencanaan, (2) penerapan, (3) pengamatan, (4) refleksi. Deskripsi pra aksi, siswa kelas V SD Negara 5 Kediri yang menjajaki modul pelajaran pembelajaran jasmani serta berolahraga merupakan 25 siswa, terdiri atas 13 siswa putra serta 12 siswa putri. Dalam pendidikan game tenis meja dengan metode memegang Bet banyak siswa yang cenderung kurang bergairah. Bersumber pada hasil uji pra siklus, dikenal kalau cuma terdapat sebagian siswa yang telah sanggup memegang Bet dengan baik ataupun mendapatkan nilai 65 ke atas. Dari hasil belajar metode memegang Bet cuma terdapat 5 siswa (20\%). Dari informasi tersebut, menampilkan kalau hasil belajar siswa dalam game tenis meja rendah. Buat membetulkan serta tingkatkan hasil belajar siswa dalam proses pendidikan tenis meja, hingga hendak dicoba aksi modifikasi Bet dengan memakai papan. Hasil observasi, terdapat 3 siklus yang diterapkan buat menuntaskan serta menanggapi kasus yang terjalin di dalam kelas. Pada tiap siklus masing-masing memakai bet dalam game tenis meja dalam aktivitas belajar mengajar yang berlangsung serta siswa lagi melaksanakan uji performance. Aktivitas berikutnya sehabis observasi dini ialah perencanaan, penerapan, pengamatan dan refleksi terhadap aksi. Dari keadaan dini, siswa menampilkan hasil belajar tenis meja dengan media modifikasi bet yang lumayan bagus dengan persentase siswa yang tuntas 52\% ataupun 13 siswa sebaliknya siswa yang belum tuntas 48\% ataupun dekat 12 siswa.

Pada siklus I diperoleh hasil ketuntasan belajar yang kurang optimal, yaitu cuma 13 siswa (52\%) yang menggapai kriteria tuntas, sebaliknya sisanya sebanyak 12 orang siswa belum tuntas.

Tabel 1. Deskripsi Data Hasil Belajar table tennis melalui teknik holding bet pada siswa sekolah dasar tahun ajaran 2020/2021 (Akhir Siklus I)

\begin{tabular}{cccc}
\hline Aspek yang Diukur & Kriteria & Jumlah Anak & Prosentase \\
\hline Ketuntasan hasil belajar & Tuntas & 13 & $52 \%$ \\
siswa (KKM : 75) & Tidak Tuntas & 12 & $48 \%$ \\
\hline Jumlah & & 25 & $100 \%$ \\
\hline
\end{tabular}

Pada akhir siklus II menjadi 18 siswa (72\%) mencapai kriteria tuntas, dan 7 siswa (28\%) yang belum Tuntas.

Tabel 2. Deskripsi Data Hasil Belajar table tennis melalui teknik holding bet pada siswa sekolah dasar tahun ajaran 2020/2021 (Akhir Siklus II)

\begin{tabular}{cccc}
\hline Aspek yang Diukur & Kriteria & Jumlah Anak & Prosentase \\
\hline Ketuntasan hasil belajar & Tuntas & 18 & $72 \%$ \\
siswa (KKM : 75) & Tidak Tuntas & 7 & $28 \%$ \\
\hline Jumlah & & 25 & $100 \%$ \\
\hline
\end{tabular}


Pada akhir siklus III terjadi peningkatan menjadi 23 siswa (92\%) mencapai kriteria tuntas dan $2(8 \%)$ siswa yang belum tuntas.

Tabel 3. Deskripsi Data Hasil Belajar table tennis melalui teknik holding bet pada siswa sekolah dasar tahun ajaran 2020/2021 (Akhir Siklus III)

\begin{tabular}{cccc}
\hline Aspek yang Diukur & Kriteria & Jumlah Anak & Prosentase \\
\hline Ketuntasan hasil belajar & Tuntas & 23 & $92 \%$ \\
siswa (KKM : 75) & Tidak Tuntas & 2 & $8 \%$ \\
\hline Jumlah & & 25 & $100 \%$ \\
\hline
\end{tabular}

\section{PEMBAHASAN}

Lewat kenaikan yang terjalin semenjak diberikan perlakuan pada siklus I, II serta III bisa disimpulkan bahwa pendidikan tenis meja lewat metode holding bet pada siswa sekolah dasar tahun ajaran 2020/2021 bisa pada siswa kelas IV SD Negara 5 Kediri bisa bertambah. Bersumber pada hasil refleksi siklus I, II serta siklus III yang sudah dicoba oleh periset, hingga terjalin pergantian kenaikan pendidikan yang nampak sepanjang riset. Mencermati dari hasil riset yang sudah dicoba, diambil kesimpulan selaku berikut: riset perlakuan pada kelas yang mempunyai sebagian tahapan penerapan perlakuan terdiri dari Siklus I, II, serta III meliputi: perencanaan, aksi, observasi serta refleksi. Prosedur dalam riset ini direncanakan 3 siklus. Pada riset pra siklus dikenal kalau siswa kurang efisien dalam game tenis meja di kelas IV SD Negara 5 Kediri. Pada siklus I game tenis meja bertambah dimana tingkatan ketuntasan siswa menggapai 52\% ataupun sebanyak 13 siswa dengan nilai rata- rata 67, 28. Pada siklus II game tennis meja terus menjadi disukan siswa teruji dengan meningkatnya ketuntasan siswa sebanyak 18 tuntas (72\%) dengan rata- rata 70, 6.

\section{DAFTAR PUSTAKA}

Dimyati, Mudjiono. 2013. Belajar \& Pembelajaran. Jakarta: Rineka Cipta.

Hodges, L. 2007. Step to Success. Tenis Meja. Tingkat Pemula. Jakarta: Raja Grafindo Persada Iskandar, A. 2012. Panduan Penelitian Tindakan Kelas bagi Guru. Jakarta: Bestari Buana Murni.

Kristiyanto, A. 2010. Penelitian Tindakan Kelas (PTK) Dalam Pendidikan Jasmani dan Kepelatihan Olahraga. Surakarta : Univeersity Press.

Kusmaedi, N., et. al. 2005. Pembelajaran Olahraga Pilihan (Tenis Meja). Departemen Pendidikan Nasional. Jakarta.

Simpson, P. 2004. Teknik Bermain Ping Pong. Bandung: Pionir Jaya.

Sugiyono. 2011. Metode Penelitian Pendidikan. Bandung: Alfabeta.

Suryabrata, S. (2003). Metodologi Penelitian. Jakarta: PT. Raja Grafindo Persada.

Susilo. 2007. Penelitian Tindakan Kelas. Bandung : Alfabeta.

Sutikno, S. 2013. Belajar \& Pembelajaran. Lombok: Holistica.

Wardhani, I., et. al. 2007. Penelitian Tindakan Kelas. Jakarta: Universitas Terbuka. 